Dhaka Univ. J. Biol. Sci. 26(1): 59-68, 2017 (January)

\title{
EFFECT OF INDUSTRIAL EFFLUENTS ON SEED GERMINATION AND SEEDLING GROWTH OF RICE
}

\author{
M RAFiQUL ISLAM ${ }^{1}$, GKM MUSTAFIZUR RAHMAN², \\ M Abu SALEQUE ${ }^{3}$ AND MJ UdDiN* \\ Department of Soil, Water and Environment, University of Dhaka, \\ Dhaka-1000, Bangladesh
}

Key words: Effluents, Seed germination, Seedling growth, Rice

\begin{abstract}
An experiment was conducted during T. Aman 2010 and Boro 2010-11 seasons to determine the effect of industrial effluents on seed germination and seedling growth of rice. In both the seasons, all the effluents and city waste water (CWW) had no effect on rice seed germination except pharmaceutical effluent. Pharmaceutical effluent showed the lowest seed germination. City waste water gave the highest shoot length $(8.40$ and $5.38 \mathrm{~cm})$ and root length $(8.06$ and 6.35 $\mathrm{cm}$ ) in the T. Aman and Boro seasons, respectively. Pharmaceutical effluent gave the highest shoot-root ratio of 10.49 while tannery effluent gave lowest ratio of 0.91. In both T. Aman and Boro seasons, seedling weight with and without endosperm, seedlings dry weight, seedling strength were found higher with CWW. During T. Aman and Boro seasons, relative germination ratio showed higher with a beverage effluent but relative shoot and root elongation ratio were found higher with CWW managed treatment.
\end{abstract}

\section{Introduction}

Human activities such as waste water irrigation, solid waste disposal, sludge application, use of chemical fertilizers, vehicular exhaust and industrial activities are the main sources of soil contamination with heavy metals ${ }^{(1)}$. Usually the industries, through their effluents pollute different water bodies e.g. lake, canal, pond, river, sea etc. Pollutants may be toxic with organic and inorganic or dissolve and suspended solids(2). Thus, water pollution is the result of addition of large amount of toxic materials ${ }^{(3)}$. The major causes of water pollution can be classified as municipal, agricultural and industrial wastes. Industrial wastewater usually contains specific and readily identifiable chemical compounds ${ }^{(4)}$. The effluents generated by various processes in industries are directly discharged without any treatment into the nearby water body.

Results demonstrated that the increase or decrease of water $\mathrm{pH}$ impacts on the increase of temperature, biological oxygen demand (BOD), chemical oxygen demand (COD), heavy metals and toxic chemicals(5). The colloidal particle in the waste water

*Author for correspondence: <mjuddin66@yahoo.com>. 1Bangladesh Rice Research Institute (BRRI), Rajshahi, Bangladesh. ${ }^{2}$ Department of Soil Science, Bangabandhu Sheikh Mujibur Rahman Agricultural University, Gazipur, Bangladesh. ${ }^{3}$ Soil Science Division, Bangladesh Rice Research Institute, Gazipur, Bangladesh. 
increases the turbidity(6). Various chemical pollutants such as nitrates, nitrites, fluorides, arsenic, and copper, zinc, nickel, detergents, hydrocarbons and radio nucleoside are the components of the industrial effluents. Industrial effluents also carry oil, grease, gasoline and waste lubricating oil. Some of these spills cause obvious and even pronounced damage to plants, fishes, birds, as well as mammals ${ }^{(7)}$. Waste water delayed germination and earlier leaf senescence are the two most important causes which influence to the final yield loss ${ }^{(8)}$. The extent of damage of the toxic effluent adversely affect germination, root elongation, rate of root growth, shoot elongation, stem growth, panicle emergence, and filling of rice grain ${ }^{(9)}$. A study reported that the growth of Cicer arietinum seedling reduced due to application of high concentrations Khoh-e-Noor mill effluent ${ }^{(10)}$. The deleterious effect of ordnance factory effluent on pea seed germination and early growth was reported ${ }^{(11)}$.

The present study was undertaken to determine the effect of industrial effluents on seed germination and seedling growth of rice.

\section{Materials and Methods}

The present study comprised of five industrial effluents, namely polyvinyl, dyeing, pharmaceutical, beverage, tannery, along with mixed waste water (MWW e.g. canal water contaminated with effluents from many industries), city waste water (CWW) and control (underground water). Industrial effluent samples were collected from discharge points of the respective sources. Polyvinyl, dyeing, beverage industries were located at Bangla Bazar of Shreepur Upazila, Gazipur, pharmaceutical industry from Bhalukha Upazila, Mymensingh and tannery industries from Hazaribag, Dhaka were selected. A mixed effluent sample was collected from a cannel that received different types of industrial effluents. Gazipur municipal waste water was collected to represent city waste water. The control water was collected from a deep tube well, BRRI, Gazipur. The experiment was laid out in complete randomized design with three replications.

The experiment was conducted in consecutive T. Aman and Boro seasons, 2010-11. BRRI dhan 49 and BRRI dhan 29 were used as a test variety in T. Aman and Boro seasons, respectively. The experiment with the effluents includes germination test and seedling quality. The germination test was carried out in sterile Petri dish where Whatman No. 1 filter paper was placed on it and $10 \mathrm{ml}$ each effluent was added to each Petri dish of respective treatment daily just to allow the seeds to get favorable moisture for germination and growth. Fifty seeds were placed in the Petri dish at room temperature $\left(30-32^{\circ} \mathrm{C}\right.$ in T. Aman rice and $20-22^{\circ} \mathrm{C}$ in Boro rice). The experiment was carried out for a period of 14 days to allow the last seed germination. The results were determined by counting the number of germinated seed, measuring the length of shoot and root $(\mathrm{cm})$, shoot - root ratio (shoot length/root length), fresh seedling weight with endosperm (mg), fresh seedling weight without endosperm $(\mathrm{mg})$, seedling dry weight $(\mathrm{mg})$, seedling strength $(\mathrm{mg} / \mathrm{cm})$ (seedling dry weight/shoot length) at 14th day of the experiment. 
Finally data were analyzed through IRRI Stat windows version 4.3. The ratio of germination and elongation were calculated ${ }^{(9)}$.

\section{Results and Discussion}

Percent germination: In T. Aman rice control treatment showed the highest per cent germination (96) (Table 1). Except pharmaceutical effluent treatment, all other effluent treatments and CWW gave the statistically similar germination percentage over the control. Pharmaceutical effluent treatment recorded the lowest germination (91\%). In Boro season, control gave the 95 per cent germination. Polyvinyl effluent treatment gave the similar germination per cent to that of control. Dyeing and mixed effluents showed the similar germination percentage (93). Both pharmaceutical effluent and CWW treatments tended to decrease in germination than the control. The highest seed germination $(96 \%)$ was found by beverage effluent while the lowest seed germination (91\%) was recorded in tannery effluent. The reasons of low germination by tannery effluent may be due to their high concentration of heavy metal pollutants. The seed germination of Boro variety was checked by pharmaceutical and tannery effluent. Pharmaceutical and tannery effluent treated seeds sprouted but after that the radicle turned yellowish and blackish and finally they died. It may be due to osmotic inhibition of water absorption, moreover, heavy metal toxicity inhibiting the functions of essential enzymes ${ }^{(12)}$.

In the present study, germination and growth were reduced significantly by pharmaceutical and tannery effluents in Boro season but in T. Aman season although germination and growth of seedlings were affected but not completely suppressed. Similar observations have been reported for seed germination in corn,(13-17), wheat, Vigna spp. and P. juliflora(18). Pharmaceutical effluent treated seeds of BR14 and BR16 rice varieties in Boro rice sprouted but after sprouting the radicle turned blackish in color and $\operatorname{died}^{(7)}$. Different concentrations of Koh-e-Noor mill effluent and marble industry effluent reduced germination of Cicer arietinum ${ }^{(10)}$.

Shoot length: Shoot length was affected significantly by the different types of effluent both in T. Aman and Boro rice (Table 1). In T. Aman rice, control gave the shoot length of $7.92 \mathrm{~cm}$. The treatment by polyvinyl, dyeing and beverage effluents decreased shoot length than the control by $0.91,0.09$ and $0.18 \mathrm{~cm}$, respectively. The CWW and MWW slightly increased in shoot length than that of control treatment. The reason of shoot length increment may be due to the contents of soluble mineral nutrients. A considerable decreased in shoot length was found in the pharmaceuticals and tannery industries effluents. The pharmaceutical effluent had shoot length of $3.83 \mathrm{~cm}$ and that in the tannery waste was $5.04 \mathrm{~cm}$. Pharmaceutical effluent showed the higher amount of $\mathrm{Fe}, \mathrm{Mn}, \mathrm{Cu}$ and $\mathrm{Pb}$ which exerted toxic effect on rice plants leading to decreased shoot growth. A similar observation was noticed ${ }^{(19)}$. In Boro rice, control treatment recorded the shoot length of 
$4.96 \mathrm{~cm}$ where polyvinyl effluent had $0.25 \mathrm{~cm}$ higher shoot length than that of control. Beverage effluent, CWW and mixed effluent treatments increased in shoot length than that of control water by $0.42,0.35$ and $0.09 \mathrm{~cm}$, respectively. Here, the shoot length increased, as these effluent may contain less toxic pollutant than the control treatment. Dyeing effluent recorded the lowest shoot length of $4.50 \mathrm{~cm}$ indicating that the shoot length is sensitive to dyeing effluent in Boro rice. Pharmaceutical and tannery effluents showed the zero shoot length due to dying of seedling. Some industrial effluents enhanced shoot length as compared to control which may be due to nutritional enrichment (e.g. nitrogenous fertilizers) of effluents. A similar observation was also reported $^{(7)}$. Different concentrations of Koh-e-Noor mill effluent and marble industry effluent affected the shoot length of Cicer arietinum ${ }^{(10)}$. Similarly the length weight of 15 days old sunflower seedlings decreased significantly with increasing concentrations of tannery effluent ${ }^{(20)}$.

Root length: Effect of root length is shown in Table 1. Root length was affected significantly by the tested effluent samples both in T. Aman and Boro rice varieties. In T. Aman season, control water showed root length of $7.06 \mathrm{~cm}$. Polyvinyl, dyeing, beverage and tannery effluents decreased shoot length than the control water by 2.41, 0.54, 1.10 and $1.53 \mathrm{~cm}$, respectively. City waste had $1.0 \mathrm{~cm}$ and mixed effluent had $0.08 \mathrm{~cm}$ higher root length than that of control. A considerable reduce in root length was found in pharmaceutical effluent. Pharmaceutical effluent recorded the root length of only 0.39 $\mathrm{cm}$. Pharmaceutical effluent caused adverse effect to root length in T. Aman rice might be due to its osmotic inhibition. Moreover, heavy metal toxicity inhibiting the functions of essential enzymes ${ }^{(12)}$. During Boro rice season, control treatment gave root length of 3.93 $\mathrm{cm}$. The polyvinyl effluent had $0.30 \mathrm{~cm}$ lower root length than that of control. The CWW gave the highest root length of $6.35 \mathrm{~cm}$ followed by beverage effluent of $5.69 \mathrm{~cm}$. Mixed effluent showed $1.34 \mathrm{~cm}$ higher root length over the control. Dyeing effluent gave the lowest root length of $3.51 \mathrm{~cm}$ indicating that root length is sensitive to dyeing effluent in Boro rice varieties. Pharmaceutical and tannery effluents showed the zero root length due to dyeing of seedling. Some industrial effluents enhanced root length over control which may be due to their nutritional enrichment (e.g. nitrogenous fertilizer) of effluents. The inhibitory effect of effluents of chemical industry on root and shoot growth of wheat was also noticed ${ }^{(21)}$. Due to the application of high concentration effluents reduced the root length of leafy vegetables ${ }^{(9)}$.

Shoot root ratio: Industrial effluents significantly affected the shoot - root ratio both in T. Aman and Boro rice varieties (Table 1). During T. Aman rice, control water recorded shoot - root ratio of 1.61. All the treatments except pharmaceutical effluent showed the lowest shoot - root ratio than that of control. A remarkable increase in shoot root ratio (10.49) was found in pharmaceutical effluent. It might be due to negative impact of pharmaceutical effluent on root length $(0.39 \mathrm{~cm})$ in T. Aman rice varieties. In Boro rice 
varieties, the highest shoot - root ratio (1.49) was found in control treatment. Polyvinyl effluent had 0.38 and dyeing effluent had 0.06 unit lower shoot root ratio over control. Beverage effluent decreased in shoot root ratio than the control by 0.55 unit. Mixed effluent had the similar shoot root ratio to that of beverage effluent. City waste had 0.58 unit lower shoot root ratio over the control. Due to dying of sprouting seedlings, no shoot root ratio was observed with pharmaceutical and tannery effluents during Boro rice season.

Table 1. Effect of different industrial effluents on seed germination, shoot length, root length of T. Aman and Boro rice seedlings.

\begin{tabular}{lcccccccc}
\hline \multirow{2}{*}{$\begin{array}{l}\text { Treatments } \\
\text { (effluent types) }\end{array}$} & \multicolumn{2}{c}{ Germination $(\%)$} & \multicolumn{2}{c}{ Shoot length $(\mathrm{cm})$} & \multicolumn{2}{c}{ Root length $(\mathrm{cm})$} & \multicolumn{2}{c}{ Shoot-root ratio } \\
\cline { 2 - 9 } & T. Aman & Boro & T. Aman & Boro & T. Aman & Boro & T. Aman & Boro \\
\hline Control & 96 & 95 & 7.92 & 4.96 & 7.06 & 3.93 & 1.16 & 1.49 \\
Polyvinyl & 95 & 95 & 7.10 & 4.71 & 4.65 & 3.63 & 1.55 & 1.11 \\
Dyeing & 96 & 93 & 7.82 & 4.49 & 6.52 & 3.51 & 1.37 & 1.44 \\
Pharmaceutical & 91 & 92 & 3.83 & - & 0.39 & - & 10.49 & - \\
Beverage & 96 & 96 & 7.74 & 5.35 & 5.96 & 5.69 & 1.31 & 0.96 \\
Tannery & 95 & 91 & 5.04 & - & 5.53 & - & 0.91 & - \\
CWW & 95 & 95 & 8.40 & 5.38 & 8.06 & 6.35 & 1.04 & 0.92 \\
MWW & 94 & 96 & 8.25 & 5.05 & 7.14 & 5.27 & 1.21 & 0.97 \\
LSD 0.05 & 4 & NS & 0.81 & 0.25 & 2.33 & 2.04 & 1.55 & 0.69 \\
CV $(\%)$ & 2 & 3 & 6.60 & 3.90 & 3.90 & 3.10 & 7.50 & 6.30 \\
\hline
\end{tabular}

Fresh weight per seedling with endosperm: The fresh weight per seedling with endosperm was affected significantly by tested industrial effluents both in T. Aman and Boro rice varieties (Table 2). In T. Aman rice, control treatment had the fresh weight per seedling with endosperm of $67 \mathrm{mg}$. The minimum decrease in fresh weight per seedling of $4 \%$ than that of control was found both in polyvinyl and beverage effluent and the maximum decrease $(33 \%)$ was recorded at pharmaceutical effluent. Tannery effluent showed the decrease in fresh weight per seedling with endosperm than the control by $13 \%$. Dyeing effluent, city waste water and mixed effluent showed an increase in fresh weight per seedling with endosperm than the control by 7, 18 and $6 \%$, respectively. In Boro rice, control showed the fresh weight per seedling with endosperm of $58 \mathrm{mg}$. All the effluents and city waste water except dyeing effluent showed an increase in fresh weight per seedling with endosperm than the control. The maximum increase $(21 \%)$ was recorded with CWW while the minimum increase of $2 \%$ was found in polyvinyl effluent. Dyeing effluent showed a decrease in fresh weight per seedling with endosperm than the control treatment by $3 \%$. Pharmaceutical and tannery effluents showed zero weight due 
to dying of seedling. Different concentrations of Koh-e-Noor mill and marble industry effluents affected the fresh weight per seedling of Cicer arietinum $^{(10)}$.

Fresh weight per seedling without endosperm: Fresh weight per seedling without endosperm was affected significantly by industrial effluents both in T. Aman and Boro rice varieties (Table 2). During T. Aman rice, control treatment had the fresh weight per seedling without endosperm of $39 \mathrm{mg}$. Polyvinyl had $18 \%$ and beverage effluent had $5 \%$ lower weight than that of control. Pharmaceutical effluent showed the maximum decrease in fresh weight per seedling without endosperm of $62 \%$ followed by tannery effluent of $31 \%$. Dyeing effluent, CWW and MWW showed an increase in fresh weight per seedling without endosperm than the control. The highest increase (31\%) was recorded in CWW and the minimum increase (2\%) was recorded in MWW. In Boro rice, control showed fresh weight per seedling without endosperm of $34 \mathrm{mg}$. All effluents and city waste water except dyeing effluent showed an increase in fresh weight per seedling without endosperm than the control. The maximum increase $(32 \%)$ was recorded with city waste while minimum increase (3\%) was found in polyvinyl effluent. Pharmaceutical and tannery showed zero weight due to dying of seedling. Different concentrations of Koh-e-Noor mill and marble industry effluents affected the dry weight per seedling of Cicer arietinum ${ }^{(10)}$. Fresh weight of 15 days old sunflower seedling decreased significantly with increasing concentrations of tannery effluent ${ }^{(20)}$.

Dry weight per seedling: Significant variation of dry weight per seedling was observed both in T. Aman and Boro rice due to the application of different industrial effluents (Table 2). In T. Aman rice, control treatment gave the dry weight per seedling of $3.95 \mathrm{mg}$. Polyvinyl effluent had 17\% and beverage effluent had 5\% lower dry weight per seedling than that of control. Dyeing effluent, CWW and mixed effluent increased in dry weight per seedling than the control by 15, 32 and $10 \%$, respectively. A remarkable reduce in dry weight per seedling was observed in the pharmaceuticals and tannery effluents. The pharmaceutical effluent gave the dry weight of $1.50 \mathrm{mg}$ while in tannery it was $2.75 \mathrm{mg}$. During Boro rice, control recorded dry weight per seedling of $3.67 \mathrm{mg}$. Polyvinyl, beverage effluents and CWW gave the similar dry weight to that in control. Both in dying and mixed effluents treatments reduced dry weight per seedling as compared to control by $9 \%$. Pharmaceutical and tannery showed zero weight due to dyeing of seedling. A similar observation was also noticed ${ }^{(10)}$ where it was reported that variety P-21 of Cicer arietinum in all marble and ARL effluents increased in dry weight of seedlings in all treatment as compared to control but variety P-2000 decreased in all effluent treatments. A reduction in dry weight was reported with the increase in sewage sludge treatments ${ }^{(22)}$.

Seedling strength: Seedling strength varied significantly among the industrial effluents both in T. Aman and Boro rice (Table 2). In T. Aman rice, control water had the seedling strength of $0.6 \mathrm{mg} / \mathrm{cm}$. Mixed effluent had the similar seedling strength to that of control. 
Dyeing, tannery effluents and CWW had positive impact on seedling strength. Dyeing, tannery effluents and CWW treatments increased seedling strength compared to control by 16,10 and 26\%, respectively. However, polyvinyl, pharmaceutical and beverage effluents showed negative impact on seedling strength. The above effluents reduced seedling strength than that of control by 8,22 and $2 \%$, respectively. In Boro rice, control showed the seedling strength of $0.74 \mathrm{mg} / \mathrm{cm}$. Except polyvinyl effluent all other effluents and CWW reduced seedling strength than the control. Polyvinyl effluent gave $7 \%$ higher seedling strength than that of control. Pharmaceutical and tannery showed zero seedling strength due to dying of seedling. Seedling strength indicates the quality of seedlings. Good quality seedlings contained relatively higher seedling strength value. Among the treatments, CWW and polyvinyl treatments gave the better quality rice seedlings in $\mathrm{T}$. Aman and Boro rice, respectively with higher seedling strength values.

Table 2. Effect of different industrial effluents on seedling weight with and without endosperm, seedling dry weight, seedling strength of T. Aman and Boro rice seedlings.

\begin{tabular}{|c|c|c|c|c|c|c|c|c|}
\hline \multirow[t]{2}{*}{$\begin{array}{l}\text { Treatments } \\
\text { (effluent types) }\end{array}$} & \multicolumn{2}{|c|}{$\begin{array}{l}\text { Seedling wt. (mg) } \\
\text { with endosperm }\end{array}$} & \multicolumn{2}{|c|}{$\begin{array}{l}\text { Seedling wt. (mg) } \\
\text { without endosperm }\end{array}$} & \multicolumn{2}{|c|}{$\begin{array}{l}\text { Seedling dry wt. } \\
(\mathrm{mg})\end{array}$} & \multicolumn{2}{|c|}{$\begin{array}{l}\text { Seedling strength } \\
(\mathrm{mg} / \mathrm{cm})\end{array}$} \\
\hline & T. Aman & Boro & T. Aman & Boro & T. Aman & Boro & T. Aman & Boro \\
\hline Control & 67 & 58 & 39 & 34 & 3.95 & 3.67 & 0.50 & 0.74 \\
\hline Polyvinyl & 64 & 59 & 32 & 35 & 3.29 & 3.67 & 0.46 & 0.79 \\
\hline Dyeing & 72 & 56 & 44 & 29 & 4.55 & 3.33 & 0.58 & 0.73 \\
\hline Pharmaceutical & 45 & - & 15 & - & 1.50 & - & 0.39 & - \\
\hline Beverage & 64 & 69 & 37 & 42 & 3.77 & 3.67 & 0.49 & 0.68 \\
\hline Tannery & 58 & - & 27 & - & 2.75 & - & 0.55 & - \\
\hline CWW & 79 & 70 & 51 & 45 & 5.21 & 3.67 & 0.63 & 0.68 \\
\hline MWW & 71 & 66 & 41 & 41 & 4.19 & 3.33 & 0.50 & 0.65 \\
\hline $\mathrm{LSD}_{0.05}$ & 7 & 12 & 7 & 10 & 0.77 & 0.87 & 0.11 & 0.18 \\
\hline CV $(\%)$ & 7 & 14 & 12 & 21 & 12.10 & 18.80 & 12.30 & 19.30 \\
\hline
\end{tabular}

Relative germination ratio (RGR): In T. Aman rice, polyvinyl effluent recorded the highest (99\%) relative germination ratio (RGR) where tannery and CWW effluent showed similar RGR (Table 3). Dyeing, beverage and mixed effluents showed 1\% higher than that of polyvinyl effluent. The lowest $(96 \%)$ RGR was found in pharmaceutical effluent. In Boro rice, the polyvinyl and beverage effluent showed the highest (99 to 101\%) RGR. The RGR decreased in dyeing and CWW effluent than polyvinyl effluent by 1 and $2 \%$, respectively. Mixed effluent had the similar RGR to that of dyeing effluent. Pharmaceutical effluent gave the lowest (95\%) RGR. It was found that pharmaceutical effluent recorded the lowest RGR both in T. Aman and Boro rice varieties. RGR was sensitive to pharmaceutical effluent which was reported earlier ${ }^{(9)}$. The germination rate is decreased with the increased concentration of industrial effluents and these results are correlated with the findings of others ${ }^{(10)}$. 
Relative shoot elongation ratio (RSER) of the germinated seeds are shown in Table 3. In T. Aman rice, polyvinyl effluent had $90 \%$ RSER. Dyeing effluent gave $8 \%$ and beverage effluent showed higher (9\%) than that of polyvinyl effluent. Mixed effluent recorded the highest (106\%) followed by CWW (104\%). A notable lower RSER was found in the treatments of pharmaceutical (48\%) and tannery effluents (64\%). The lowest RSER indicates that the RSER is sensitive both in pharmaceutical and tannery effluents. In Boro rice, the lowest (91\%) RSER was observed in dyeing effluent. RSER increased with the polyvinyl and mixed effluents than control by 4 and $12 \%$, respectively. Beverage and CWW effluent showed the highest (108\%) RSER. Pharmaceutical and tannery effluents showed zero RSER due to dying of seedling after sprouting. The relative shoot elongation ratio of the germinated seeds increased with increasing concentration of effluents ${ }^{(9)}$. Similar findings have also been reported ${ }^{(23)}$.

Relative root elongation ratio (RRER) of the germinated seeds are shown in Table 3. In T. Aman rice, polyvinyl effluent had $66 \%$ RRER. Dyeing, beverage and tannery effluents showed an increase in RRER than the polyvinyl effluent by 26,18 and $12 \%$, respectively. Among the treatments, CWW had the highest (114\%) RRER followed by mixed effluent $(101 \%)$. A notable decreased was found in the pharmaceutical effluent. The pharmaceutical effluent had only $5 \%$ which means the RRER was highly inhibited by pharmaceutical effluent. In Boro rice, the lowest (89\%) RRER was found in dyeing effluent. Polyvinyl, beverage and mixed effluents showed an increase in RRER than the dyeing effluent by 29, 56 and 45\%, respectively. Among the treatments, CWW had the highest (161\%) RRER. Pharmaceutical and tannery effluents showed zero RRER due to dying of seedling after sprouting. The average root elongation ratio of mustard (Brassica campestris), amaranth stem (Amaranthus gangeticus) and radish (Raphanus sativus) were decreased with increasing concentration of effluents ${ }^{(9)}$.

Table 3. Effect of different industrial effluents on relative germination ratio, relative shoot elongation ratio and relative root elongation ratio of T. Aman and Boro rice seedlings.

\begin{tabular}{lcccccccc}
\hline \multirow{2}{*}{$\begin{array}{l}\text { Treatments } \\
\text { (effluent types) }\end{array}$} & \multicolumn{2}{c}{$\begin{array}{c}\text { Relative germination } \\
\text { ratio }\end{array}$} & & \multicolumn{2}{c}{$\begin{array}{c}\text { Relative shoot } \\
\text { elongation ratio }\end{array}$} & & \multicolumn{2}{c}{$\begin{array}{c}\text { Relative root } \\
\text { elongation ratio }\end{array}$} \\
\cline { 2 - 3 } Polyvinyl & T. Aman & Boro & & T. Aman & Boro & & T. Aman & Boro \\
Dyeing & 98.96 & 100.00 & & 89.65 & 94.96 & & 65.86 & 92.37 \\
Pharmaceutical & 94.79 & 96.84 & & 48.36 & - & & 5.52 & - \\
Beverage & 100.00 & 97.89 & & 98.74 & 90.52 & & 92.35 & 89.31 \\
Tannery & 100.00 & 101.05 & & 97.73 & 107.86 & & 84.42 & 144.78 \\
CWW & 98.96 & 95.79 & & 63.64 & - & & 78.33 & - \\
MWW & 98.96 & 100.00 & & 104.17 & 108.47 & & 114.16 & 161.58 \\
\hline
\end{tabular}


The results revealed that germination and growth of rice seedlings were highly sensitive to pharmaceutical and tannery effluents as compared to other effluents. Pharmaceutical and tannery effluents showed their deleterious effect on rice seedlings more in Boro rice than in T. Aman rice. Good seed germination and seedling growth were observed by city wastewater and beverage effluent.

\section{References}

1. Park JH, Lamb D, Paneerselvam P, Choppala G, Bolan N and Chung JW 2011. Role of organic amendments on enhanced bioremediation of heavy metal contaminated soils. J. Hazardous Materials 185: 549-574.

2. Moeller and W Dade 1992. Toxic Chemicals. In: Environmental Health. USA. pp. 2.

3. Terry LA 1996. Water pollution. Environ. Law. Prac. 4: 19-29.

4. Benard J and TW Wright 1998. In: Environmental Science (The Way the World Work) 6th Edn. Prentice Mall, New Jersey.

5. Santiniketan MR and V Bharati 1994. Industrial pollution of irrigation water. In: Affordable water supply and sanitation. pp. 432-435.

6. Antonelli M and M Areeari 1999. Membrane treatment of secondary textile effluents for direct reuse. In: Advanced water treatment, Recycling and Reuse, p 409-416.

7. Hossain MT 1998. Effect of industrial effluents on growth and yield of rice (Oryza sativa L.). M. Sc. thesis. Department of Crop Botany, Bangabandhu Sheikh Mujibur Rahman Agricultural University, Gazipur.

8. Clemente R, DJ Walker and MP Bernal 2005. Uptake of heavy metals and As Brassica juncea grown in a contaminated soil in Anaicollar (Spain): The effect of soil amendments. Environ. Pollut. 33: 324-331.

9. Begum SA, MJ Alam, SS Rahman and MM Rahman 2010. Effect of industrial effluents on the germination and seedling growth of three leafy vegetables. Bangladesh J. Sci. Ind. Res. 45 (2): 101-104.

10. Nawaz S, SM Ali and AYasmin 2006. Effect of industrial effluents on seed germination and early growth of Cicer arietinum. J. Biol. Sci. 6(1): 49-54.

11. Agrawal SK, R Swanlalat and PS Deubey 1996. Biodiversity and Environment. APH Publishing Corporation. pp. 179-184.

12. Jerome G and Ferguson 1972. The cycling of mercury through the environment. Water Res. 6:989-1008.

13. Mahmood S, A Hussain, Z Saeed and M. Athar 2005. Germination and seedling growth of corn (Zea mays L.) under varying levels of copper and zinc. Intl. J. Environ. Sci. Technol. 2: 269274.

14. Jamal SN, MZ Iqbal and MAthar 2006a. Effect of aluminum and chromium on the germination and growth of two Vigna species. Int. J. Environ. Sci. Technol. 3: 53-58.

15. Jamal SN, MZ Iqbal and M Athar 2006b. Effect of aluminum and chromium on the growth and germination of mesquite (Prosopis juliflora (Swartz.) DC). Intl. J. Environ. Sci. Technol. 3: 173-176. 
16. Jamal SN, MZ Iqbal and M Athar 2006c. Phytotoxic effect of aluminum and chromium on the germination and early growth of wheat (Triticum aestivum) varieties Anmol and Kiran. Intl. J. Environ. Sci. Technol. 3: 203-208.

17. Jamal SN, MZ Iqbal and M Athar 2006d. Evaluation of two wheat varieties for phytotoxic effect of mercury on seed germination and seedling growth. Agric. Consp. Sci. 71: 41-44.

18. Shafiq M, MZ Iqbal and M Athar 2008. Effect of lead and cadmium on germination and seedling growth of Leucaenaleucocephala. J. Appl. Sci. Environ. Manage. 12: 61-66.

19. Yamaguchi $\mathrm{T}$ and $\mathrm{S}$ Aso 1977. Chromium from the stand point of plant nutrition. Effect of $\mathrm{Cr}$ concentration on the germination and growth of plants. J. Sci. Soil Manure 29(48): 466-470.

20. Hussain F, SA Malik, M Athar, N Bashir, UY, M Hassan and S Mahmood 2010. Effect of tannery effluents on seed germination and growth of two sunflower cultivars. African J. Biot. 9(32): 5113-5120.

21. Sisodia GS and OM Bedi 1985. Impact of chemical industry effluent on seed germination and early growth performance of wheat on India. J. Ecol. 12 (2):189-192.

22. Iqbal TMT and ML Smith 1996. Physiological changes of pea seeds quality due to aging. Ann. Bangla Agric. 6:27-34.

23. Ramamoorthy KD, Kalavathi and M Paramasivam 1992. Maintenance of vigour and availability of stored pea seeds. J. Agron. Crop Sci. 169: 223-228.

(Manuscript received on 16 November, 2016; revised on 15 December, 2016) 